tion of that group and on the late Ordovician transgression is overstressed.

The Eskdale Granite, the exposed part of the largely concealed, early batholith cannot be directly related to the Borrowdale Volcanic rocks in the way that Soper suggests. The thick, acid, pyroclastic sheets he refers to are, generally, dacitic $\left(\mathrm{SiO}_{2} 66-68 \mathrm{wt} \%\right)$ and although they may represent plutons that rose to such high crustal levels that they explosively tore themselves apart, there was probably little left to form an intrusion of any size. Furthermore, a comparison of incompatible element geochemistry of rhyolitic rocks from the Borrowdale Volcanic Group with the Eskdale Granite shows the latter to be more evolved (O'Brien et al. 1985). Any relationships between the volcanic and plutonic activity must be seen as part of the long term evolution of magmas generated from sub-crustal and/or crustal sources within the destructive plate margin environment that existed in the Lake District during this period. All that can be argued is that repeated passage of magmas through the crust during the eruption of the Borrowdale Volcanic Group would produce a suitably annealed system of channelways to serve as sites for the rise of later, highlevel intrusions.

Evidence for early (Caradoc) folding of the Borrowdale Volcanic Group centres on the Ulpha Syncline (see Soper \& Moseley, 1978), which appears to have a more easterly trend than later folds of the main, early Devonian deformation phase and to be truncated by the late Caradoc unconformity at the base of the Windermere Group. However, anticlinal folds in the Borrowdale Group, like those in the overlying Silurian strata, are periclinal structures and thus the trend of the associated synclines can be anomalous. Our mapping shows that the axial plane trace of the Ulpha Syncline converges with that of the adjacent, more northerly trending, Black Coombe Anticline so that in the Duddon Valley, near Ulpha (grid reference SD 1993), these folds die out leaving no more than a sharp change in the strike of the volcanic rocks. There is, therefore, no good evidence to indicate that the orientation of early folds differed from that of later ones. We have yet to resurvey the Coniston/Torver area in the region of the pronounced overstep of the Upper Ordovician Coniston Limestone Formation onto the Borrowdale Volcanic Group, but there seems no reason to doubt the occurrence of periclinal folds in this area or that such folds are truncated by the unconformity. At present we are prepared to accept the existence of folds pre-dating the unconformity but consider these to be coaxial with those of the later, main deformation and see no reason to relate them to the Lake District batholith. Our recent field mapping does not support the suggestion by Firman \& Lee that the Ulpha Syncline could be a drape structure developed during the intrusion of the batholith. In the Whitfell (SD 1593) to Buckbarrow (SD 1591) area the Ulpha Syncline is clearly truncated and, therefore, post-dated by the Eskdale granodiorite which is thought to be part of the early batholith.

We consider the Caradoc deformation to be unrelated to batholith emplacement and to be part of a prolonged, discontinuous deformation phase which commenced sometime between late Llanvirn and early Caradoc time. It was responsible for partial inversion of the earlier Skiddaw Group basins, causing the initiation of the main Lake District Anticline and the associated sub-Borrowdale Volcanic Group unconformity (Downie \& Soper, 1972; Wadge, 1972). Minor structures relatable to this earlier episode have not been identified (pre-cleavage folds in the Skiddaw Group are earlier still). They are either very rare or coaxial with, and hence indistinguishable from, later structures of Caradoc or early Devonian age. Renewed development of the Lake District Anticline in Caradoc time would uplift the volcanics and produce a 'horst' without recourse to the intrusion of granitic magma at the same time. The intrusion would follow, as its radiometric age suggests, being emplaced early in the tensional regime under which the Silurian basins developed.

Soper suggests that the Caradoc compressional episode might represent a 'close encounter' between Avalonia and Laurentia rather than a true collision. The distinction is, perhaps, subjective. We would advocate such a "close encounter' to initiate the Lake District Anticline in preBorrowdale times. This was followed by:

1. A tensional episode in which the Borrowdale Volcanic Group was erupted.

2. A compressional episode to produce the Caradoc folds and uplift.

3. A tensional episode in which the batholith was emplaced and the Silurian basins opened.

4. A compressional episode, the main, early Devonian deformation phase.

If the episode 4 represents the final docking of Avalonia into the re-entrant between Laurentia and Baltica (Soper \& Hutton, 1984), then the earlier ones could represent transpressional and transtensional episodes as Avalonia slipped sinistrally along the irregular margin of Laurentia.

This letter is published by permission of the Director, British Geological Survey (NERC).

\section{Further references}

DOWNIE, C. \& SOPER, N. J. 1972. Age of the Eycott volcanic Group and its conformable relationship to the Skiddaw Slates in the English Lake District. Geological Magazine 109, 259-68.

O'Brien, C., Plant, J. A., Simpson, P. R. \& Tarney, J. 1985. The geochemistry, metasomatism and petrogenesis of the granites of the English Lake District. Journal of the Geological Society of London 142, 113957.

SOPER, N. J. \& HutToN, D. H. W. 1984. Late Caledonian sinistral displacements in Britain: implications for a three-plate collision model. Tectonics 3, 781-94.

SOPER, N. J. \& MoselEy, F. 1978. Structure. In The Geology of the Lake District (ed. F. Moseley), pp. 45-67. Yorkshire Geological Society Occasional Publication no. 3 .

WADGE, A. J. 1972. Sections through the Skiddaw-Borrowdale unconformity in eastern Lakeland. Proceedings of the Yorkshire Geological Society 39, 179-98.

BARRY WEBB

DAVE MILLWARD

ERIC JOHNSON

TONY COOPER

British Geological Survey

Windsor Court

Windsor Terrace

Newcastle upon Tyne

NE2 4HB, U.K.

\section{March 1987}

\section{Reply}

It is apparent that the Lake District B.G.S. group (Webb et al., above) do not accept our thesis, developed from that of 
Firman \& Lee (1986), that the early batholith and the Borrowdale vulcanicity are genetically related. They reject our arguments against the likelihood that a large buoyant granitic body could have been emplaced in the upper crust during the late Ashgill to mid-Silurian basin-deepening episode without countering them, and deploy two arguments in support of their view which call for a rejoinder.

It is unrealistic to suppose that the acid pyroclastic rocks of the Borrowdale Group were erupted from the same magma body as formed the Eskdale intrusion, and this was not implied. The working hypothesis adopted by the Sheffield group is based on recent advances in the understanding of the relationship between ash flow eruptions and subvolcanic magma bodies (e.g. Smith, 1979; Lipman, 1984). We relate the Airy's Bridge and later pyroclastic flow units to episodes of caldera collapse, while the Eskdale body was subsequently emplaced at a high level in the volcanic pile, almost reaching the base of the Airy's Bridge Formation in Wasdale. This model requires the Eskdale intrusion to represent a later, and therefore potentially a more chemically evolved, magma than the pyroclastic deposits.

Secondly, high-level magma bodies which erupt acid pyroclastic flows do not destroy themselves in the process: they commonly erupt some $10 \%$ of their volume (Lipman, 1984). A conservative estimate of the volume of the Airy's Bridge parental magma body is $1200 \mathrm{~km}^{3}$. A proportion of this must have remained at depth and now exists beneath the Borrowdale crop, representing an important component of the batholith. The same applies to the higher ash flow units and those which may have been removed by erosion.

In our view therefore, a strong volcanological case can be made for linking the early batholith to the extrusives, as well as arguments based on crustal dynamics. Indeed, had we the wit to see it, this link could have been made years ago, on the basis of Oliver's (1961) recognition of major ash flows in the Scafell area and Bott's (1974) demonstration that the extent of the hidden batholith coincides approximately with the Borrowdale Volcanic crop.

Turning to the Caradoc deformation of the Borrowdale Group, we question whether this essentially took the form of flexural folding related to regional compression, and find it surprising that several years into the mapping programme the B.G.S. group is still firmly wedded to this traditional view. Detailed mapping in Langdale by M.J.B. has shown the structure to be dominated by volcanotectonic faulting and block tilting, and the folds which have previously been inferred to affect the area do not exist. It is difficult to find any evidence for Caradoc compression in the Lake District; as pointed out by Webb et al., no minor folds of that age can be proved in the Skiddaw Slates and such folds as can be discerned in the Borrowdale Group have a similar trend to the early Devonian structures in the Silurian rocks. Many previously inferred folds traces in the volcanic tract are illusory, resulting from Devonian compression of fault blocks with opposing dips; perhaps the Ulpha Syncline will prove to be of this type.

\section{Further references}

BotT, M. H. P, 1974. The geological interpretation of a gravity survey of the English Lake District and the Vale of Eden. Journal of the Geological Society of London 130, 309-31.

LIPMAN, P. W. 1984. The roots of ash flow calderas in Western North America: windows into the tops of granitic batholiths. Journal of Geophysical Research 89, $8801-41$.

OLIVER, R. L. 1961. The Borrowdale Volcanic and associated rocks of the Scafell area, English Lake District. Quarterly Journal of the Geological Society of London 117, 377-417.

Smith, R. L. 1979. Ash-flow magmatism. Geological Society of America Special Paper no. 180, 5-27.

\section{N. J. SOPER}

M. J. BRANNEY

N. A. MATHIESON

N. C. DAVIS

Department of Geology

University of Sheffield

Sheffield, S1 3JD

U.K.

4 March 1987 